\title{
DETERMINAN PENDAPATAN PEDAGANG KAKI LIMA (PKL) KULINER MALAM DI KECAMATAN UMBULHARJO
}

\author{
Suripto ${ }^{1)}$, Ahmad Sodikin' ${ }^{2}$ \\ Email : ${ }^{1)}$ suripto@ep.uad.ac.id, ${ }^{2)}$ ahmadsodikin96.ass@gmail.com \\ ${ }^{1,2}$ ) Program studi Ekonomi pembangunan Fakultas Ekonomi dan Bisnis Universitas Ahmad Dahlan
}

\begin{abstract}
Abstrak
Penelitian ini bertujuan adalah untuk mengetahui pengaruh modal usaha, jumlah tenaga kerja, jam operasional, lama usaha, variasi menu, terhadap pendapatan pedagang kaki lima sektor kuliner malam di kecamatan Umbulharjo. Penelitian ini adalah penelitian asosiatif dengan jenis penelitian kuantitatif dan menggunakan data primer. Adapun sampel yang digunakan didalam penelitian ini yaitu pedagang kaki lima sektor kuliner malam di Kecamatan Umbulharjo berjumlah 32 kuesioner dan diambil dengan menggunakan metode purposive sampling. Untuk metode analisis yang digunakan pada penelitian ini yaitu analisis regresi linier berganda. Hasil analisis menunjukkan bahwa variabel modal usaha, jam operasional, lama usaha dan variasi menu berpengaruh secara signifikan terhadap pendapatan pedagang kaki lima sektor kuliner malam, sedangkan variabel jumlah tenaga kerja tidak berpengaruh signifikan terhadap pendapatan pedagang kaki lima sektor kuliner malam.
\end{abstract}

Kata Kunci: Modal Usaha, Jam Operasional, Lama Usaha, Variasi Menu, Jumlah Tenaga Kerja, dan Pendapatan.

\begin{abstract}
This study aims to determine the effect of venture capital, the number of workers, operating hours, business hours, menu variations, on the income of street vendors in the night culinary sector in Umbulharjo sub-district. This research is associative research with quantitative analysis and uses primary data. The samples used in this study were street vendors in the culinary sector of the night in Umbulharjo District, totaling 32 questionnaires and were taken using a purposive sampling method. The analysis method used in this study is the multiple linear regression analysis. The report results showed that the variables of venture capital, operating hours, business length, and menu variations significantly influence the income of street vendors in the culinary sector. In contrast, the variable number of workers does not considerably change the income of street vendors in the night culinary sector.
\end{abstract}

Keywords: Business Capital, Operating Hours, Business Length, Menu Variations, Number of Workers, and Income.

\section{PENDAHULUAN}

Permasalahan tenaga kerja di Indonesia berkaitan erat denga dua hal yang mendasar seperti tingkat pengangguran terbuka sangat relatif tinggi dan pembengkakan sektor informal yang di tandai rendahnya produktifitasnya kerja dan penghasilan berupa pendapatan di sektor tersebut. Negara- Negara berkembang termasuk Indonesia tentunya akan melaksananakan upaya pembangunan baik sektor formal maupun informal. Adapun upaya pembangunan yang di lakukan Negara berkembang terdapat di berbagai sektor yaitu sektor ekonomi, sektor politik, sektor sosial dan budaya serta menunjang pertumbuhan perekonomian. Menurut Qamaruddin, Sapar, Risal, \& Hamid (2019) bahwa pemerintah harus memberikan komitmen dukungan kekuatan berupa kebijakan yang berkaitan dengan masyarakat, industri, intermediasi dan sumber daya serta teknologi sebagai upaya dalam menciptakan iklim usaha yang kondusif bagi lahirnya industri kreatif. Konsistensi peran pemerintah diperlukan untuk terus menciptakan iklim yang nyaman bagi UKM, terutama bagi pengusaha baru. Pemerintah juga perlu membuat aturan yang memudahkan pengusaha mengembangkan bisnisnya (Hamid et al., 2019).

Tingkat pendapatan merupakan salah satu tujuan didirikannya sebuah usaha. Suatu usaha masih berjalan dan layak untuk dipertahankan walaupun sebenarnya masih ada beberapa hal yang lain selain pendapatan 
yang bisa menjadi bahan pertimbangan untuk meneruskan sebuah usaha. Dengan memperhatikan jumlah pendapatan, akan diketahui apakah suatu usaha mendapatkan laba untung atau malah labar ugi. Peranan sektor informal semakin membesar dengan potensi yang ada setelah terjadinya beberapa krisis ekonomi di Indonesia. Dalam kondisi ini, sektor informal menjadi alternatif bagi pekerja agar tetap mempunyai penghasilan. tetapi sektor informal tetap menjadi pilihan tenaga kerja sebagai penopang pemenuhan kebutuhan hidup pekerja bersama keluarganya. Banyaknya bidang sektor informal yang berpotensi untuk dikembangkan menjadi salah satu bidang usaha yang dapat menghasilkan pendapatan, serta dapat menyerap tenaga kerja. Salah satunya adalah pedagang kaki lima kuliner malam

Pedagang kaki lima kuliner malam adalah salah satu pedagang industri kecil dan berusaha dibidang produksi yang di tekuni sesuai keahlian masing masing. untuk memenuhi kebutuhan kelompok tertentu khususnya masyarakat. Penjualan dilaksanakan di tempat-tempat yang strategis akan memperoleh keuntungan yang tinggi. Pedagang kaki lima kuliner malam juga menguntungkan bagi konsumen dari masyarakat ekonomi menengah ke bawah, karena Pedagang kaki lima kuliner malam mampu menyediakan barangbarang kebutuhan dengan harga yang relatif murah dan terjangkau. Sektor informal yang berkembang di Yogyakarta salah satunya adalah sektor perdagangan dan eceran. Sektor yang menduduki urutan pertama adalah penyediaan akomodasi dan makan minum yang sebesar $10,23 \%$.

Berdasarkan Gambar 1 dapat ditarik kesimpulan bahwa perkembangan pada sektor perdagangan salah satu sektor penyumbang Ptoduk Domestik Regional Btuto (PDRB) yang cukup potensial di Daerah Istimewa Yogyakarta (DIY). Perkembangan perekonomian DIY di nilai berkembang cukup pesat terutama dalam sektor perdagangan. Keberadaan tempat perdagangan merupakan salah satu indikator utama kegiatan perekonomian daerah secara nyata di suatu wilayah.

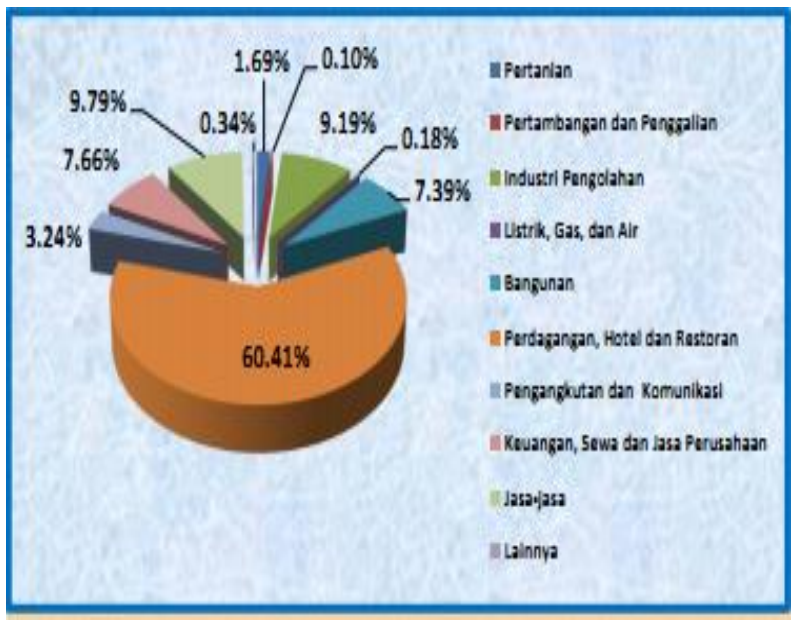

Gambar 1. Persentase PDRB Yogyakarta

Sumber : https://yogyakarta.bps.go.id/ tahun 2017
Pedagang kaki lima kuliner malam yang ada di kecamatan Umbulharjo Kota Yogyakarta biasanya tersebar hampir di beberapa jalan yang dinilai strategis, dengan menggunakan bahu jalan, trotoar, bahkan fasilitas umum. Keberadaan Pedagang Kaki Lima kuliner malam dipandang telah melanggar peraturan pemerintah daerah, mengganggu tata ruang kota dan ketertiban umum. Akan tetapi, peran Pedagang Kaki Lima kuliner malam harus diakui telah membantu kondisi sosial dan ekonomi rakyat saat ini seperti di lihat konstribusi sektor perdagangan terhadap PDRB Kota Yogyakarta.

Kecamatan Umbulharjo merupakan salah satu kecamatan terluas di Kota Yogyakarta. Kecamatan Umbulharjo merupakan wilayah kecamatan yang memiliki berbagai pedagang baik pedagang besar, sedang, kecil atau di kenal Pedagang Kaki Lima untuk memperoleh pendapatan mata pencaharian seseorang dengan di tandai banyaknya pembangunan, perdagangan makanan dan minuman serta berbagai infrastruktur maupun peningkatan proses kegiatan perekonomian untuk selalu menunjang aktivitas kegiatan ekonomi di kecamatan Umbulharjo salah satu banyaknya perguruan tinggi, serta sebagai pusat kegiatan sentral wilayah perkotaan Yogyakarta.

Kecamatan Umbulharjo merupakan pusat dari perdagangan ,pendidikan dan jasa, serta pusat pelayanan umum dan fasilitas umum yang cukup memadai dibandingkan dengan kecamatan yang lainnya. Adapun jumlah Pedagang Kaki Lima di Kecamatan Umbulharjo, pedagangan kaki lima Kecamatan Umbulharjo terbanyak di Kelurahan Semaki Kulon sebanyak 74 orang. Kemudian Kelurahan Warung Boto sebanyak 56 orang dan Kelurahan Muja muju sebanyak 50 orang dan di tempatkan kelurahan lainnya. Hal ini menunjukkan bahwa kelurahan semaki kulon terkait jumlah pedagang kaki lima lebih tinggi dibandingkan dengan kelurahan lainnya.

Kelurahan Semaki Kulon terpilih menjadi wilayah penelitian karena beberapa alasan, pertama wilayah Kelurahan Semaki Kulon berdekatan dengan pusat perkotaan Kota Yogyakarta. Kedua, wilayah Kelurahan Semaki Kulon maupun Kelurahan Warung boto berada di tengah tengah banyaknnya aktivitas perekonomian, perdagangan besar maupun kecil serta perguruan tinggi. Adapun Sumbangan sektor perdagangan terhadap PDRB D.I.Y relatif lebih besar dibandingkan dengan PDRB daerah lainnya. Sumbangan sektor perdagangan terhadap PDRB D.I.Y rata-rata sebesar 8,59 \% pada tahun 2017 (https://yogyakarta.bps.go.id/ tahun 2017)

Alasan lain memilih di Kecamatan Umbulharjo dengan melihat PDRB ADHB \& ADHK se kecamatan Yogyakarta menunjukn bahwa Kecamatan Umbulharjo merupakan salah satu Kecamatan yang mampu menciptakan nilai tambah bruto sebesar 7,54 trilyun rupiah dan menjadi penyumbang terbesar PDRB Kota Yogyakarta terbesar (Gambar 2). Kecamatan ini memberikan konstribusi sebesar 24,09 persen. 
Penyumbang kedua adalah kecamatan Gondomanan sebesar 16,71 persen atau 53 trilyun rupiah .Kecamatan Danurejan dengan jumlah penduduk 19.128 jiwa menempati posisi ketiga dengan nilai tambahan sebesar 9,09 persen atau 2,84 trilyun.

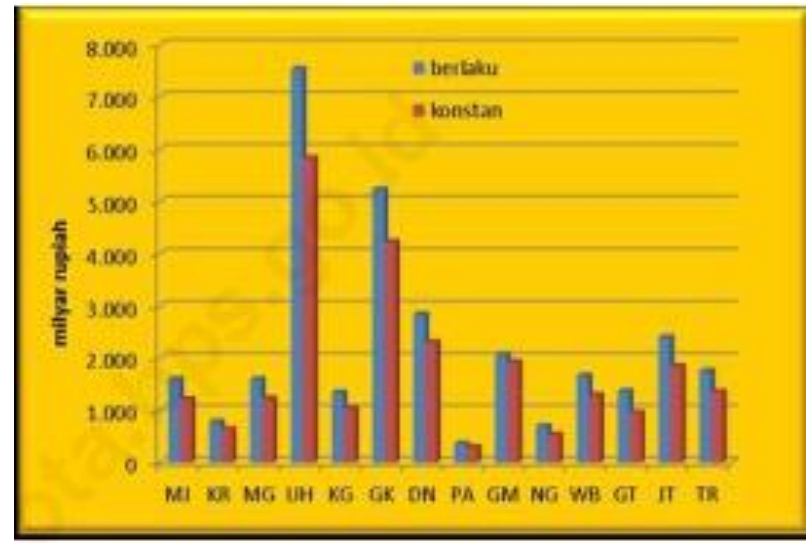

Gambar 2. PDRB Kecamatan Kota Yogyakarta Tahun 2017

Sumber: Statistik Yogyakarta dalam angka, Tahun 2017.

Keberadaan pedagang Kaki Lima Kuliner Malam di Kecamatan Umbulharjo memiliki konstribusi paling besar terhadap PDRB se Kecamatan Yoagyakarta di bandingan Kecamatan lainnya, pedagang Kaki Lima Kuliner malam merupakan bagian sektor perdagangan industri kecil pengolahan makanan dan minuman. Dalam memulai suatu usaha berdagang, terdapat berbagai faktor yang dapat menentukan pendapatan pedagang. Faktor yang mempengaruhi pendapatan pedagang selain modal usaha yaitu Jumlah tenaga kerja, jam operasional, lama usaha dan variasi menu.

Berdasarkan uraian latar belakang diatas maka dapat dirumuskan masalah dalam penelitian ini yaitu pertama, apakah modal usaha, jumlah tenaga kerja, jam operasional, lama usaha, dan variasi menu berpengaruh terhadap tingkat pendapatan pedagang kaki lima kuliner malam di Kecamatan Umbulharjo.

\section{METODE}

\section{Jenis Penelitian}

Penelitian ini menggunakan tipe penelitian asosiatif dengan pendekatan kuantitatif. Menurut sugiyono dalam Satwika Adhi Nugraha \& Ramantha (2015) Metode kuantitatif merupakan metode penelitian yang berlandaskan pada filsafat positisisme, di gunakan untuk meneliti pada populasi atau sampel tertentu, pengumpulan data dengan menggunakan instrument penelitian, serta analisis data bersifat kuantitatif/statistik, fakta/angka/ hasil pengukuran yang memiliki satuan dan nilai nol adalah absolute dengan tujuan untuk menguji sebuah Hipotesis yang telah di tetapkan.

\section{Populasi dan Sampel}

Populasi merupakan keseluruhan dari objek atau subjek ataupun individu pada suatu wilayah yang akan diteliti
(Hamid \& Patra, 2019). Adapun populasi yang digunakan pada penelitian ini yaitu pedagang kaki lima sektor kuliner malam di Kecamatan Umbulharjo. Sampel adalah kumpulan atau bagian dari populasi yang terpilih dengan prosedur tertentu yang bisa merepresentasikan populasi (Hamid \& Patra, 2019). Untuk penentuan jumlah sampel pada penelitian ini menggunakan metode purposice sampling. Adapun rincian perhitungan jumlah sampel sebagai berikut:

Tabel 1.

Perhitungan Sampel Penelitian

\begin{tabular}{|c|l|c|c|c|}
\hline No & $\begin{array}{c}\text { Kelurahan } \\
\text { PKL kuliner malam }\end{array}$ & $\begin{array}{c}\text { Unit } \\
\text { Populasi }\end{array}$ & $\boldsymbol{s}=\frac{\boldsymbol{n x \boldsymbol { s }}}{\boldsymbol{N}}$ & $\begin{array}{c}\text { Unit } \\
\text { sampel }\end{array}$ \\
\hline 1 & Kel. Semaki & 74 orang & $74 / 281 \times 30$ & 8 \\
\hline 2 & Kel. Tahunan & 32 Orang & $32 / 281 \times 30$ & 4 \\
\hline 3 & Kel. Warung boto & 56 Orang & $56 / 281 \times 30$ & 6 \\
\hline 4 & Kel. Muja muju & 50 Orang & $50 / 281 \times 30$ & 6 \\
\hline 5 & Kel. Sosutan & 29 Orang & $29 / 281 \times 30$ & 3 \\
\hline 6 & Kel. Pandeyan & 28 Orang & $28 / 281 \times 30$ & 3 \\
\hline 7 & Kel. Giwangan & 12 Orang & $12 / 281 \times 30$ & 2 \\
\hline & \multicolumn{1}{|c|}{ Jumlah } & 281 Orang & & 32 PKL \\
\hline
\end{tabular}

Dalam penelitian ini jumlah sampel yang diteliti sebanyak 32 responden atau sampel. Responden tersebut adalah para pedagang kaki lima Kuliner malam yang berada di Kecamatan Umbulharjo maupun yang berjajaran di sepanjang jalan atau pinggir jalan.

\section{Metode Analisis}

Teknis analisis data ini di gunakan analisis menggunakan analisis regresi liniear berganda.Teknik analisis regresi yang di gunakan adalah regresi berganda dengan tujuan untuk mengetahui pengaruh modal usaha, jumlah tenaga kerja, jam operasional, lama usaha serta variasi menu terhadap pendapatan pedagang kaki lima kuliner malam di Kecamatan Umbulharjo. Adapun persamaan regressi sebagai berikut :

\section{$Y=\beta_{0}+\beta_{1} X_{1}+\beta_{2} X_{2}+\beta_{3} X_{3}+\beta_{4} X_{4}+\beta_{5} X_{5}+e$}

Keterangan:

$\mathrm{Y}=$ Adalah pendapatan pedagangkaki lima kuliner malam yang diperoleh tiap berdagang (Ribu Rupiah)

$\mathrm{X}_{1}=$ Adalah modal usaha, dalam pengertian ekonomi, modal yaitu barang atau uang yang bersama dengan faktor - faktor produksi tanah dan tenaga kerja untuk menghasilkan barang dan jasa (Rupiah).

$\mathrm{X}_{2}=$ Tenaga kerja yang digunakan dalam proses produksi, semakin banyak tenaga kerja yang di sediakan maka dapat memberi kemudahan bagi para pembeli sehingga meningkatkan minat seseorang untuk membeli sehingga akan mudah memperoleh pendapatan. Jumlah tenaga kerja (Orang)

$\mathrm{X}_{3}=$ Adalah jam operasional, analisis Jam Operasional merupakan bagian dari teori ekonomi mikro khususnya pada teori penawaran tenaga kerja 
yaitu tentang kesediaan individu untuk bekerja dengan harapan memperoleh penghasilan lebih atau tidak bekerja dengan konsekuensi mengorbankan penghasilan yang seharusnya ia dapatkan. Kesediaan tenaga kerja untuk bekerja dengan jam operasional yangpanjang ataupun pendek adalah merupakan keputusan individu (Wahyono,2017). Jam Operasional (Jam ).

$\mathrm{X}_{4}=$ Lama usaha adalah lamanya seorang pelaku usaha atau bisnis menekuni bidang usahanya, semakin lama menekuni bidang usaha perdagangan akan makin meningkatkan pengetahuan tentang selera ataupun perilaku konsumen. Keterampilan berdagang makin bertambah dan semakin banyak pula relasi bisnis maupun pelanggan yang berhasil di jaring. Lama usaha (Tahun)

$\mathrm{X}_{5}=$ Adalah Variasi Menu, setiap penambahan variasi menu akan membuka peluang bertambahnya omzet penjualan. Variasi menu (Jumlah Banyaknya menu)

$\beta_{1}, \beta_{2}, \beta_{3}, \beta_{4}, \beta_{5}=$ Koefisien variabel

$$
\begin{aligned}
& \text { hasil terhadap variabel } \\
& \mathrm{X}_{1}, \mathrm{X}_{2}, \mathrm{X}_{3}, \mathrm{X}_{4}, \mathrm{X}_{5} \\
= & \text { Variabel } \text { Eror. }
\end{aligned}
$$

Model regresi tersebut diuji apriori teoritik dengan cara membandingkan kesesuaian tanda di antara variabel estimasi yang di gunakan dengan teori ekonomi. Sehubungan dengan pemakaian metode regresi berganda dengan teknik Cross sectioan maka untuk menghindari pelanggaran asumsi asumsi model klasik, perlu diadakan pengujian asumsi klasik yang meliputi uji multikorelasi, dengan bantuan SPSS versi 20 for windows .Uji multikolonieritas bertujuan untuk menguji apakah model regresi ditemukan adanya korelasi antar variabel bebas (independen) dilakukan dengan melihat nilai tolerance lebih > lebih dari 0,1 dan nilai VIF kurang dari< kurang dari 10 berarti tidak adamultikolonieritas. Bila ternyata dalam model regresi terdapat multikolonieritas, maka harus menghilangkan variabel independen yang mempunyai korelasi tinggi (Imam Ghozali, 2011).

Uji selanjutnya adalah uji parsial (Uji t ), uji ini dilakukan dengan cara membandingkan nilai statistik $\mathrm{t}$ hitung dengan titik kritis menurut t- tabel.Apabila nilai statistik $t$ hitung hasil perhitungan lebih tinggi dibandingkan nilai t-tabel, maka hipotesis alternatif diterima ((I. Ghozali, 2011) Uji serentak (Uji f ) pada dasarnya menunjukkan apakah semua variabel bebas yang dimasukkan dalam model mempunyai pengaruh secara bersama-sama terhadap variabel terikat.(Gujarati, 2010) Uji ini dilakukan dengan membandingkan nilai $F$ menurut tabel. Bila nilai $\mathrm{F}$ hasil perhitungan lebih besar daripada nilai $\mathrm{F}$ menurut tabel, maka secara serentak variabel variabel modal usaha, jumlah tenaga kerja, jam operasional, lama usahaserta variasi menu berpengaruh terhadap pendapatan pedagang kaki lima kuliner malam. Seperti halnya ketika kita melakukan uji t, keputusan dalam melaksanakan uji $\mathrm{F}$ juga bisa dilihat dari tingkat signifikansinya.

Uji kebaikan model dilihat dari Koefisien determinasi (R2) pada intinya mengukur seberapa jauh kemampuan model dalam menerangkan variasi variabel dependen.Nilai koefisien determinasi adalah antara nol dan satu $(0<\mathrm{R} 2<1)$. Nilai R2 yang kecil berarti kemampuan variabel-variabel independen dalam menjelaskan variasi variabel dependen amat terbatas. Nilai yang mendekati satu berarti variabel-variabel independen memberikan hampir semua informasi yang dibutuhkan untuk memprediksi variasi variabel dependen (Gujarati, 2010).

\section{HASIL DAN PEMBAHASAN}

Kecamatan Umbulharjo Kota Yogyakarta adalah merupakan salah satu Kecamatan dari 14 Kecamatan di Kota Yogyakarta yang terletak di sisi Selatan Kota Yogyakarta dengan ketinggian dari permukaan laut 113 $M$ dengan Luas Wilayah $+811,4800$ Ha yang berbatasan dengan: Sebelah Barat dengan Kecamatan Mergangsan dan Kecamatan Pakualaman, sebelah timur: Kecamatan Kotagede, Kec. Banguntapan dan Kabupatan Bantul, sebelah Selatan Kabupaten Bantul, Sebelah Utara : Kecamatan Gondokusuman.

Analisis diskriptif merupakan analisis data guna bagaimana mendiskripsikan atau memberikan gambaran secara umum terkait data yang di peroleh atau terkumpul atas dasar hasil penelitian seperti memberikan sebuah gambaran kondisi responden yang dapat memberikan sebuah informasi tambahan dengan tujuan memahami penelitian tersebut.Dengan mengambarkan berbagai profil dari data yang di peroleh, di olah. Penelitian tersebut saling berhubungan antara variabel satu dengan variabel lainnya .

\begin{tabular}{|ccc|}
\hline & $\mathrm{Rp}$ Pendapatan permalam \\
& 1.500 .0 & $\mathrm{Rp}$ \\
& $00-\ldots$ & 100.00 \\
$\mathrm{Rp500.}$ & $\mathrm{Rp}$ & $0-\mathrm{Rp} \ldots$ \\
$\mathrm{O} 00-$ & 1.000 .0 \\
$\mathrm{Rp} .$. & $00-\ldots$ & \\
\hline
\end{tabular}

Gambar 3. Distribusi Frekuensi Variabel Pendapatan Per Malam

Sumber : Data primer yang di olah, 2019

Berdasarkan Gambar 3, menunjukan bahwa distribusi frekuensi variabel Pendapatan perm alam yang di peroleh pedagang kaki lima kuliner malam di Kecamatan Umbulharjo yaitu rata - rata sebesar antara Rp 100.000 - Rp 500.000 dengan jumlah 13 Responden atau $40 \%$ (persen). Pendapatan yang di peroleh responden sebesar Rp 500.000 - Rp 1.000.000 dengan jumlah 7 Responden atau $22 \%$ ( persen). Pendapatan yang di peroleh responden sebesar antara Rp 1.000.000 - Rp 1.500.000 dengan jumlah 7 responden atau $22 \%$ ( persen). Kemudian Pendapatan antara Rp 1.500.000 Rp 2.000.000 dengan jumlah 5 responden atau $16 \%$. 
Oleh karena itu di simpulkan pendapatan tertinggi permalam yang di peroleh responden di hari biasa berjualan yaitu antaraRp 1.500 .000 s.d. Rp 2.000.000 sebanyak 5 responden atau $16 \%$.

\section{Analisis Regresi Berganda}

Dalam Analisis Regresi Linear Berganda merupakan analisis persamaan Regresi untuk mengetahui Variabel indenpeden penelitian tersebut.Dan penelitian ini yaitu menggunakan model analisis Regresi Linear Berganda. Analisis ini di gunakan untuk mengetahui seberapa besar pengaruh variabel independent terhadap Variabel dependent seperti Pengaruh Variabel modal usaha, Jumlah tenaga kerja, Jam Operasional, Lama usaha, serta Variasi menu terhadap Pendapatan Pedagang Kaki Lima Kuliner Malam di Kecamatan Umbulharjo.

Adapun beberapa persamaan regresi dapat di lihat dari tabel hasil uji koefisiensi dengan menggunakan perhitungan output SPSS for windows versi 20 terhadap Variabel indenpeden yang di peroleh sebagai berikut :

Tabel 2.

Hasil Analisis Regresi Berganda

\begin{tabular}{|c|c|c|c|c|}
\hline \multirow[t]{2}{*}{ Model } & \multicolumn{2}{|c|}{$\begin{array}{l}\text { Unstandardized } \\
\text { Coefficients }\end{array}$} & \multirow[t]{2}{*}{$\mathrm{t}$} & \multirow[t]{2}{*}{ Sig. } \\
\hline & B & Std. Error & & \\
\hline (Constant) & - 594231.554 & 258556.99 & -2.298 & .030 \\
\hline Modal & .451 & .218 & 2.066 & .049 \\
\hline $\begin{array}{l}\text { JumlahTenaga } \\
\text { Kerja }\end{array}$ & 26305.961 & 58212.292 & .452 & .655 \\
\hline $\begin{array}{l}\text { Jam } \\
\text { Operasional }\end{array}$ & 90905.327 & 38408.970 & 2.367 & .026 \\
\hline Lama Usaha & 26769.486 & 9588.374 & 2.792 & .010 \\
\hline Variasi Menu & 78225.691 & 33637.859 & 2.326 & .028 \\
\hline
\end{tabular}

\section{Uji Apriori}

Uji apriori ekonomi yang terkait dengan tanda dan intensitas hubungan ekonomi dengan cara membandingkan kesesuaian antara variabel independen dan hipotesis yang telah ditentukan. Variabel independen dalam penelitian ini adalah tenaga kerja, bahan bakar, lama memasak, bahan pembantu, pengalaman, nira, dan modal tetap. Kesesuaian antara hipotesis dan hasil dalam penelitian ini dapat dilihat dalam tabel di bawah ini :

Tabel 3.

Hasil Uji Apriori Teoritik

\begin{tabular}{|l|c|c|c|}
\hline \multicolumn{1}{|c|}{ Variabel } & Hipotesis & Hasil & Kesimpulan \\
\hline Modal kerja & + & + & Sesuai \\
\hline Jumlah tenaga kerja & + & + & Sesuai \\
\hline Jam Operasional & + & + & Sesuai \\
\hline Lama usaha & + & + & Sesuai \\
\hline Variasi menu & + & + & Sesuai \\
\hline
\end{tabular}

\section{Uji Asumsi Klasik}

Uji Multikolinearitas dilakukan dengan melihat nilai Tolerance jika nilai tolerance lebih besar > dari 0.10 maka terjadi multikolinearitas terhadap data yang di uji sedangkan jika nilai tolerance lebih kecil < dari 0.10 maka artinya terjadi multikolinearitas terhadap data yang di uji dan dengan melihat nilai Varian inflation factor $(V I F)$ jika nilai VIF lebih kecil < dari 10.00 maka artinya tidak multikolinearitas terhadap data yang di uji sedangkan nilai VIF lebih besar > dari 10.00 maka artinya terjadi multikolinearitas terhadap data yang di uji. Hasil perhitungan uji multikolinearitas adalah:

Tabel 4.

Hasil Pengujian Multikolinearias

\begin{tabular}{|c|c|c|c|}
\hline $\begin{array}{c}\text { Variabel } \\
\text { indenpeden }\end{array}$ & \multicolumn{2}{c|}{$\begin{array}{c}\text { Collinearity } \\
\text { Statistics }\end{array}$} & \multirow{2}{*}{ Kesimpulan } \\
\cline { 1 - 3 } Constanta & Tolerance & VIF & \\
\hline Modal usaha & 0.306 & $\begin{array}{c}3.27 \\
1\end{array}$ & $\begin{array}{c}\text { Tidak ada } \\
\text { multikoinearitas }\end{array}$ \\
\hline Jumlah tenaga kerja & 0.523 & $\begin{array}{c}1.91 \\
0\end{array}$ & $\begin{array}{c}\text { Tidak ada } \\
\text { multikoinearitas }\end{array}$ \\
\hline Jam Operasional & 0.884 & $\begin{array}{c}1.13 \\
2\end{array}$ & $\begin{array}{c}\text { Tidak ada } \\
\text { multikoinearitas }\end{array}$ \\
\hline Lama usaha & 0.516 & $\begin{array}{c}1.93 \\
6\end{array}$ & $\begin{array}{c}\text { Tidak ada } \\
\text { multikoinearitas }\end{array}$ \\
\hline Variasi menu & 0.409 & $\begin{array}{c}2.44 \\
6\end{array}$ & $\begin{array}{c}\text { Tidak ada } \\
\text { multikoinearitas }\end{array}$ \\
\hline & & \multicolumn{2}{|c}{} \\
\hline
\end{tabular}

Dapat dilihat pada Tabel 4, nilai centered VIF di semua variabel kurang dari 10 (Centered VIF<10). Oleh karena itu dapat ditarik kesimpulan bahwa semua variabel dinyatakan tidak adanya terjadi gejala multikolinearitas.

\section{Uji Statistik}

Uji F (Uji Simultan) merupakan salah satu uji yang di gunakan untuk mengetahui pengaruh variabel indenpeden secara signifikan terhadap variabel dependen . dengan menggunakan $\alpha=5 \% \mathrm{df}=\mathrm{k}-1 / \mathrm{n}-\mathrm{k}$ $=5-1 / 32-5=4$ dan 27. Maka di peroleh hasil F- tabel adalah 2.73 .

Tabel 5.

Hasil pengujian Uji simultan ( Uji F )

\begin{tabular}{|c|c|c|}
\hline F Hitung & Sig. & F- tabel \\
\hline 21.230 & 0.000 & 2.73 \\
\hline
\end{tabular}

Berdasarkan Tabel 5, dari hasil regresi yang di tunjukan pada output SPSS versi 20 nilai F- Hitung adalah sebesar 21.230 dengan tingkat signifkansi 0.000, nilai $F$ tabel pada signifkansi ( 0.05 ) adalah 2.73, Oleh karena itu $F$-hitung $>F-\operatorname{tabel}(21.230>2.73)$ ini menunjukan bahwa Ho di tolak dan Ha di terimaartinya Variabel Modal Usaha (X1), Jumlah Tenaga Kerja (X2), Jam Operasional (X3), Lama Usaha (X4) serta Variasi Menu (X5) secara bersama-sama mempengaruhi pendapatan Pedagang kaki Lima Kuliner Malam di Kecamatan Umbulharjo.

Uji parsial di gunakan untuk mengetahui apakah masing masing variabel bebas (indenpenden) apakah memiliki pengaruh terhadap variabel terikat (dependen) nya. Penelitian ini uji parsial digunakan untuk mengetahui bagaimana pengaruh Modal Usaha, Jumlah 
Tenaga Kerja, Jam Operasional, Lama Usaha serta Variasi Menu terhadap pendapatan pedagang kaki lima kuliner malam di Kecamatan Umbulharjo. Analisis yang digunakan adalah regresi linier berganda dengan jumlah 32 sampel Pedagang Kaki Lima Kuliner Malam Kecamatan Umbulharjo. Dengan taraf signifikan $\alpha=$ 0,05 dikethui nilai $t$ - tabel $\mathrm{df}=\mathrm{n}-\mathrm{k}-1=32-5-1=$ 26, ( uji satu sisi ) didapatkan nilai $t$ - tabel yaitu sebesar 2.056 .

Tabel 6.

Hasil Regresi Uji t

\begin{tabular}{|l|c|c|c|}
\hline $\begin{array}{c}\text { Variabel } \\
\text { Indenpenden }\end{array}$ & $\mathbf{t}$ - Hitung & Sig. & Keterangan \\
\hline Modal Usaha & 2.066 & 0.049 & Signifikan \\
\hline $\begin{array}{l}\text { Jumlah Tenaga } \\
\text { Kerja }\end{array}$ & 0.452 & 0.655 & $\begin{array}{c}\text { Tidak } \\
\text { signifikan }\end{array}$ \\
\hline $\begin{array}{l}\text { Jam } \\
\text { Operasional }\end{array}$ & 2.367 & 0.026 & Signifikan \\
\hline Lama usaha & 2.792 & 0.010 & Signifkan \\
\hline Variasi menu & 2.326 & 0.028 & Signifikan \\
\hline
\end{tabular}

Sumber : Data primer hasil lampiran di olah, 2019

Dari Tabel 6, disimpulkan bahwa dengan taraf signifikansi 0,05 variabel Jumlah Tenaga Kerja tidak signifikan mempengaruhi pendapatan Pedagang Kuliner Kaki Lima di kecamatan Umbularjo, sedangkan variabel Modal usaha, Jam Kerja, Lama usaha dan Variasi menu mampu mempengaruhi pendapatan pedagang Pedagang Kuliner Kaki Lima di Kecamatan Umbularjo.

\section{Nilai Koefisien Determinasi}

Koefisien determinasi $\left(\mathrm{R}^{2}\right)$ pada intinya mengukur seberapa jauh kemampuan model dalam menerangkan variasi variabel dependen. Nilai koefisien determinasi adalah antara nol dan satu $\left(0<\mathrm{R}^{2}<1\right)$. Nilai $\mathrm{R}^{2}$ yang kecil berarti kemampuan variabel-variabel independen dalam menjelaskan variasi variabel dependen.

Tabel 7.

Hasil Koefisiensi $\mathbf{R}^{2}$

\begin{tabular}{|c|c|c|}
\hline Model & R square & $\begin{array}{c}\text { Adjusted R } \\
\text { Square }\end{array}$ \\
\hline 1 & 0.803 & 0.765 \\
\hline
\end{tabular}

Berdasarkan Tabel 7, dapat dilihat bahwa Variabel Modal Usaha, Jumlah Tenaga Kerja, Jam Operasional, Lama Usaha serta Variasi Menu mampu menjelaskan variasi variabel dependen (pendapatan Pedagang Kuliner Kaki Lima) sebesar $76.5 \%$ sisanya yaitu sebesar $23.5 \%$ dijelaskan variabel lainnya yang tidak ada dalam model penelitian ini.

\section{Pembahasan Hasil Penelitian}

Variabel Modal Usaha berpengaruh positif dan signifikan terhadap pendapatan Pedagang Kaki Lima Kuliner Malam Kecamatan Umbulharjo dengan koefisien 0.451 (lihat Tabel 3), artinya bahwa jika modal usaha Pedagang Kaki Lima Kuliner Malam di Kecamatan Umbulharjo bertambah seribu rupiah maka pendapatan Pedagang Kaki Lima Kuliner Malam di
Kecamatan Umbulharjo akan bertambah sebesar 0,451 ribu Rupiah. Variabel modal berbengaruh positif terhadap pendapatan Pedagang Kaki Lima Kuliner Malam di Kecamatan Umbulharjo, ini sesui dengan penelitian (Fitria, 2013) yang menemukan bahwa modal merupakan variabel penting dalam peningkatan pendapatan pedagang di Malioboro.

Variabel Jumlah Tenaga kerja tidak mempengaruhi pendapatan Pedagang Kaki Lima Kuliner Malam di Kecamatan Umbulharjosecara positif dengan tingkat signifikansi 0,05. Variabel tenaga kerja yang tidak signifikan berpengaruh terhadap Pedagang Kaki Lima Kuliner Malam di Kecamatan Umbulharjo karena sifat usaha ini tidak memerlukan tenaga kerja yang banyak dan memerlukan tenaga kerja untuk menyajikan hidangan dan bekerja tidak brdasar jadwal tetap, sehingga tenaga kerja yang dibutuhkan tidak perlu banyak.

Variabel Jam Operasional memiliki koefisien sebesar 90905.327 dan signifikan berbengaruh positif terhadap pendapatan Pedagang Kaki Lima Kuliner Malam di Kecamatan Umbulharjo. Artinya jika jamkerja usaha Pedagang Kaki Lima Kuliner Malam di Kecamatan Umbulharjo bertambah satu jam maka akan terjadi kenaikan pndapatan Pedagang Kaki Lima Kuliner Malam di Kecamatan Umbulharjo sebesar 90905.327 Rupiah. Jamoperasional ini menjadi kendala tersendiri karena berhubungan dengan fisik pekerja yang sering mengantuk karena usaha ini dilakukan malam hari.

Variabel Lama Usaha berpengaruh positif dan signifikan terhadap pendapatan Pedagang Kaki Lima Kuliner Malam di Kecamatan Umbulharjo dengan taraf nyata 0,05 . Koefisien variabel ini sebesar 26769.486 (lihat Tabel 3), artinya jika pengalaman usaha bertambah satu tahun maka akan terjadi kenaikan pendapatan Pedagang Kaki Lima Kuliner Malam di Kecamatan Umbulharjo sebesar 26769.486 Rupiah. Variabel Lama Usaha mengukur pengalaman usaha Pedagang Kaki Lima Kuliner Malam di Kecamatan Umbulharjo, jika pengalaman naik menunjukan ada tambahan informasi dan keahlian sehingga dapat mengantisipasi danpak positif dan negatif terhadap usaha yang mereka lakukan, yang selanjutnya akan berdampak positif terhadap pendapatan mereka. Temuan ini sejalan dengan temuan penelitian Pamungkas (2016) yang menyatakan bahwa pengalaman kerja akan berdampak pada pendapatan usaha.

Variabel Variasi menu berpengaruh positif dan signifikan terhadap pendapatan Pedagang Kaki Lima Kuliner Malam di Kecamatan Umbulharjo dengan taraf signifikansi 0,05 dan memiliki koefisien 0.409, artinya jika terjadi tambahan variasi menu sebesar satu variasi menu, akan mengakibatkan kenaikan pendapatan pendapatan Pedagang Kaki Lima Kuliner Malam di Kecamatan Umbulharjo sebesar 409 Rupiah. Variasi menu tambahan akan membuat konsumen terlayani 
karena preferensi konsumen yang beraneka macam dapat terpenuhi sehingga akan meningkatkan permintaan yang selanjutnya akan meningkatkan pendapatan. Preverensi konsumen akan menentukan permintaan (Nopirin, 2000)

\section{PENUTUP}

\section{Simpulan}

Berdasarkan analisis penelitian yang telah di lakukan terhadap pendapatan Pedagang Kaki lima kuliner Malam di Kecamatan Umbulharjo, dapat di peroleh beberapa kesimpulan.

1. Modal usaha berpengaruh positif dan signifkan terhadap tingkat pendapatan pedagang kaki lima kuliner malam di Kecamatan Umbulharjo. Hal ini berarti bahwa Hipotesis yang menyatakan bahwa modal usaha berpengaruh positif dan signifikan terhadap pendapatan

2. Jumlah tenaga kerja tidak berpengaruh signifikan terhadap tingkat pendapatan pedagang kaki lima Kuliner malam di Kecamatan Umbulharjo. Hal ini berarti bahwa Hipotesis yang menyatakan bahwa Jumlah tenaga kerja tidak berpengaruh dan tidak signifikan terhadap pendapatan.

3. Jam operasional berpengaruh positif dan signifkan terhadap tingkat pendapatan pedagang kaki lima kuliner malam di Kecamatan Umbulharjo. Hal ini berarti bahwa Hipotesis yang menyatakan bahwa Jam kerja berpengaruh posistif dan signifikan terhadap pendapatan.

4. Lama Usaha berpengaruh positif dan signifikan terhadap tingkat pendapatan pedagang kaki lima kuliner malam di Kecamatan Umbulharjo Hal ini bearti bahwa Hipotesis yang menyatakan lama usaha Berpengaruh positif dan signifikan terhadap pendapatan

5. Variasi menu berpengaruh positif dan signifikan terhadap tingkat pendapatan pedagang kaki lima kuliner malam di Kecamatan Umbulharjo. Hal ini berarti bahwa Hipotesis yang menyatakan bahwa Variasi menu berpengaruh posistif dan signifikan terhadap pendapatan.

\section{Saran}

Untuk pedagang kaki lima kuliner malam di Kecamatan Umbulharjo:

1. Modal usaha merupakan variabel yang berpengaruh terhadap pendapatan pedagang kaki lima kuliner malam di Kecamatan Umulharjo. di karenakan, sebagian pedagang dalam menekuni usahanya masih memiliki modal tergolong yang sangat rendah. Oleh karena itu, Pemerintah kota Yogyakarta beserta instansi terkait hendaknya memberikan atau bantuan secara langsung seperti Bantuan langsung tunai, Pinjaman modal yang lebih lunak, dan di perlukan pemberdayaan fasilitas sarana \& prasana bagi PKL kuliner malam.

2. Jumlah tenaga kerja merupakan variabel yang tidak berpengaruh signifikan terhadap penerimaan pendapatan pedagang kaki lima kuliner malam di Kecamatan umbulharjo. Berdasarkan hasil observasi peneliti bahwa rata rata jumlah tenaga kerja yang di miliki tergolong sangat sedikit untuk di pekerjakan, Sedangkan dalam teorikal pelayanan mengatakan setiap penambahan tenaga kerja maka akan dapat meningkatkan kualitas pelayanan misalnya dalam kecepatan penyajian, kecepatan memasak menu yang di pesan oleh konsumen. Maka Untuk meningkatkan pendapatan PKL kuliner malam dapat menambah jumlah tenaga kerja. Hal ini akan berpengaruh terhadap peningkatan konsumen dan akan berpengaruh peningkatan pendapatan.

3. Jam Operasioal merupakan variabel yang berpengaruh positif dan signifikan terhadap pendapatan pendapatan pedagang kaki lima kuliner malam di Kecamatan umbularjo. Jam operasional yang di miliki pedagang tergolong masih sedang berdasarkan hasil penelitian rata -rata jam operasional $6 \mathrm{jam} / \mathrm{malam}$. Maka dari itu seorang pedagang sebaiknya memanfaatkan waktu operasional pasar secara baik, efisien, efektif, sehingga dapat meningkatkan bertambahnya pendapatan.

4. Lama usaha merupakan variabel yang berpengaruh positif dan signifikan terhadap pendapatan pendapatan pedagang kaki lima kuliner malam di Kecamatan umbularjo. Para pedagang kaki limakuliner malam telah berdagang lebih dari 20 tahun. Sebaiknya para pedagang kaki kuliner malam di Kecamatan Umbulharjo dapat selalu berinovasi, mencari sesuatu hal yang baru atas pengalaman yang sudah di miliki. Sehingga segudang pengalaman yang di miliki dapat menarik konsumen serta meningkatkan kenaikan pendapatan.

5. Variasi menu merupakan variabel yang berpengaruh positif dan signifikan terhadap pendapatan pendapatan pedagang kaki lima kuliner malam di Kecamatan Umbulharjo. Seorang penjual ketika menawarkan banyaknya menu dalam setiap dagangannya maka cendrung akan menjadi daya tarik perilaku konsumen atau seorang pembeli sesuai kebutuhnnya yang di minati, sehingga semakin banyaknya variasi menu semakin besar pengaruh terhadap pendapatan pedagang Kaki Lima Kuliner malam di Kecamatan Umbulharjo.

\section{DAFTAR PUSTAKA}

Badan Pusat Statistik Yogyakarta. (2017). Persentase PDRB Yogyakarta. Diakses pada 21 Mei 2020, dari https://yogyakarta.bps.go.id/

Fitria, N. A. (2013). Analisis Faktor-Faktor Yang Mempengaruhi Pendapatan Pedagang Tape Singkong Di Kota Probolinggo (Studi Kasus Pedagang Tape Singkong Di Jln. Soekarno Hatta, Kelurahan Ketapang, Kecamatan Kademangan, Kota Probolinggo). Jurnal Ilmiah Mahasiswa $F E B, 2(2)$.

Ghozali, I. (2011). Aplikasi Analisis Multivariete IBM SPSS. In Semarang, Universitas Diponegoro. https://doi.org/10.1017/CBO9781107415324.004 
Ghozali, Imam. (2011). Aplikasi Analisis Multivariate Dengan Program SPSS. Semarang: Badan Penerbit Universitas Diponegoro.

Gujarati, D. (2010). Dasar-dasar Ekonometrika. Buku Edisi 5 (Erlangga, ed.). Jakarta.

Hamid, R. S., Anwar, S. M., Salju, Rahmawati, Hastuti, \& Lumoindong, Y. (2019). Using the triple helix model to determine the creativity a capabilities of innovative environment. IOP Conference Series: Earth and Environmental Science, 343(1). https://doi.org/10.1088/1755-1315/343/1/012144

Hamid, R. S., \& Patra, I. K. (2019). PENGANTAR STATISTIKA UNTUK RISET BISNIS DAN EKONOMI Konsep Dasar dan Aplikasi SPSS versi 25. Banten: CV. AA. RIZKY.

Nopirin. (2000). Pengantar Ilmu Ekonomi Mikro dan Makro. In BPFE-Yogyakarta.

Qamaruddin, M. Y., Sapar, S., Risal, M., \& Hamid, R. S. (2019). STRATEGI SIAPA MAU KERJA APA DALAM PENGEMBANGAN MODEL QUADRUPLE HELIX SINERGITAS ANTARA PEMERINTAH, PERGURUAN TINGGI, INDUSTRI, DAN MASYARAKAT. Jurnal Manajemen STIE Muhammadiyah Palopo, 4(2).

Satwika Adhi Nugraha, I., \& Ramantha, I. (2015). Pengaruh Profesionalisme, Etika Profesi Dan Pelatihan Auditor Terhadap Kinerja Auditor Pada Kantor Akuntan Publik Di Bali. E-Jurnal Akuntansi, 13(3), 916-943. 